\title{
UnATI: a juventude de uma senhora Universidade
}

\author{
UnATI: the youth of a mature University
}

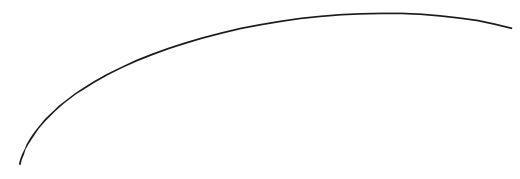

Acabo de receber um e-mail do amigo Renato Maia com a informação do IBGE que o país está envelhecendo com mais rapidez do que se previa e que a taxa de natalidade atingiu 1,8 filho por mulher, nível esperado apenas para 2043. Fernando Albuquerque, que participou da elaboração das estimativas do IBGE, diz que o Instituto, até os últimos inquéritos, trabalhava com projeções menores, mas o aumento da velocidade da queda da fecundidade observada nos últimos estudos indica que a população começará a envelhecer mais rapidamente.

Bem mais do que uma simples revisão de um cálculo estatístico, a constatação de que, antes do previsto, o Brasil terá cada vez mais idosos e menos crianças tem impacto nos cálculos de aposentadonia e traz desafios para as políticas de Estado, que terão que se adaptar a uma estrutura populacional envelhecida. Com cada vez mais velhos e menos crianças, as políticas públicas terão que ser revistas para se adaptar à realidade da população, com os investimentos em saúde ampliados para atender melhor aos idosos.

Apesar dos desafios que a queda mais intensa da fecundidade trará, não há por que ficar apavorado com a redução da população e a ampliação do grupo etánio dos idosos. Esta realidade demográfica pode ser boa ou ruim, dependendo de como a sociedade e as políticas públicas responderão à questão.

Para aqueles que trabalham na área da gerontologia, tais fatos não são novidades. Talvez, a radicalidade expressada na velocidade desta transição demográfica possa produzir ainda mais certeza de que precisamos fazer chegar às autoridades, com poder decisónio no país, a necessidade de mais investimentos e mais ênfase nas ações de Estado para este grupo populacional. 
A Revista Brasileira de Geriatria e Gerontologia, que se caracteriza pela busca de soluções, ancorada na produção científica de qualidade, sente-se fortalecida na sua missão de ampliar o debate sobre tema tão relevante e prionitánio para a sociedade brasileira.

É por este motivo que os 15 anos da UnATI, instituição responsável pela edição da RBGG, a ser comemorado em agosto de 2008, como muita intensidade e divulgação, faz parte desta estratégia de mostrar a todos que o Brasil envelheceu e que novos temas precisam ter primazia. Pretendemos atrair a atenção não apenas da comunidade científica, mas de toda a sociedade, de tal forma que todos entendam que a conquista de maior longevidade somente poderá ser devidamente usufruída se forem ofertadas condições adequadas visando à qualidade de vida. Deste modo, temos que pressionar aqueles com poder de decisão a colocaro envelhecimento humano na agenda contemporânea das prioridades do país.

De 25 a 29 de agosto teremos diversas solenidades, com a participação de inúmeras autoridades, e será reservado um dia para a apresentação da produção científica e dos avanços tecnológicos de projetos elaborados pela UnATI, muitos deles inclusive publicados na RBGG e em outros periódicos de excelência no país.

Participar dos festejos dos 15 anos da UnATI, portanto, tem um duplo aspecto. Primeiramente, o de divulgar e de ecoar para a sociedade a relevância do assunto tratado e, também, o de apresentar os inúmeros avanços científicos e compartilhar com os profissionais da área todo o esforço que vem sendo desenvolvido para que os idosos possam usufruir com qualidade, cidadania e saúde estes anos a mais que serão vividos. 